\title{
Market sensing, innovation capability and market performance: The moderating role of internal information dissemination
}

\author{
Abubaker Mohamed Ahmed ${ }^{1, *}$, Siddig Balal Ibrahim ${ }^{1}$, Abdel Hafiez Ali Hasaballah ${ }^{2}$ \\ ${ }^{1}$ Department of Business Administration, College of Business Studies, Sudan University of Science and Technology, Khartoum, \\ Sudan \\ ${ }^{2}$ Department of Business Administration, College of Business and Economics, Qassim University, Buraydah, Saudi Arabia
}

\section{A R T I C LE IN F O}

\section{Article history:}

Received 4 March 2017

Received in revised form

8 July 2017

Accepted 10 July 2017

Keywords:

Internal information dissemination

Market sensing

Innovation

Market performance

\begin{abstract}
A B S T R A C T
Market sensing and internal information dissemination are popular concepts in the field of marketing and strategic management. Scholars in these fields are appreciating the roles of market sensing and internal information dissemination in understanding the business environmental changes to sustain competitive advantages for better firm performance. However, the interaction of market sensing and internal information dissemination couched within complementarity prospective to some extend has not been empirically tested. Therefore, This study aims to investigate the moderating effect of internal information dissemination in the exchange between market sensing and innovation and how innovation mediate the relationship between market sensing and market performance. As a result of responses from 166 firms operating in Sudan, we find that internal information dissemination strengthens the positive relationship between response of market sensing and innovation. Also innovation was found to partially mediate the relationship between market sensing and market performance. The study further develops the understanding of how market sensing influence innovation and market performance indicating the positive relationship between them. In addition our work provides managerial advices to the firms in Sudan to develop market sensing as an adaptive tool for innovation and performance.
\end{abstract}

(C) 2017 The Authors. Published by IASE. This is an open access article under the CC BY-NC-ND license (http://creativecommons.org/licenses/by-nc-nd/4.0/).

\section{Introduction}

Organizations in the new economy are facing turbulent environments and strong competition (Diaz-Fernandez et al., 2015). In an environment where uncertainty and turbulence are increasing on a daily basis, adjusting to change and conditionally, being a leader for change requires innovation strategy, therefore, the need for firms to perform strategically in a global competition environment in order to compete or to increase competitive advantage while trying to preserve it are important in understanding these firms' level of sensibility (Tutar et al., 2015).

Previous studies used different approaches or point of views to specifying and classifying MS which basically used to identify the firm's opportunities and threats and to understanding the business

\footnotetext{
* Corresponding Author.

Email Address: abuhamdiii@yahoo.com (A. M. Ahmad) https://doi.org/10.21833/ijaas.2017.08.009

2313-626X/C 2017 The Authors. Published by IASE.

This is an open access article under the CC BY-NC-ND license

(http://creativecommons.org/licenses/by-nc-nd/4.0/)
}

environmental changes of the firms. In literature the resource-based view (RBV) explains the importance of developing valuable and scarce resources and capabilities (Diaz-Fernandez et al., 2015), which are said to be the source of sustainable competitive advantage. From dynamic capability point of view Teece et al. (1997) suggested that resources are developed through specialized routines that create different competencies. Moreover, Teece (2007) defined the deployment of dynamic capability as the process of sensing and seizing market chances and reconfiguring the resource base.

According to Song et al. (2015) the inconsistent empirical evidence in literature about the positive effect of market orientation (MO) on innovation motivates further research to investigate the potential moderating variables in order to explain the unstable relationship between MO and innovation for example study of Wang and Chung (2013), Grinstein (2008), and Wei and AtuaheneGima (2009). For example Wang and Chung (2013) examined the moderating role of managerial ties in MO and innovation. Likewise, the exchange of MO and firm innovativeness may depend on managerial 
attitudes towards the natural environment (Dibrell et al., 2011). Furthermore, Wei and Atuahene-Gima 2009) established that the proper reward system design is found to have effect on the exchange of MO and new product performance.

In addition, Grinstein (2008) have declared that the effect of MO on innovation strengthen when competitive environments is high, but high technology turbulence weakens it. Despite the growth in the number of variables that used as moderators in the relationship between behavioral definition of MO and innovation, to some Extend previous studies have no so far incorporated internal information dissemination as moderator in relationship between market sensing and innovation.

In this sense Yu and To (2013) declared that disseminating appropriate and timely information is an important requirement to aligning employee work attitude and other behaviors with the organizational goals. The marketing literature also provides evidence that intra-organizational dissemination of customer knowledge contributes to organizational effectiveness through inter-functional coordination, learning, and the innovation of products and services (Park et al., 2011).

Summing up the above argument this study is posits that internal information dissemination would positively affect the relationship between market sensing and innovation capability to enhance market performance, and subsequently present the data and clarify the process by which the hypotheses are tested and intricate upon the findings and their propositions for theoretical and managerial implications.

\section{Literature review and theoretical background}

\subsection{Market sensing (MS)}

Early MS is defined as continuous ability to learn about the market (Day, 2002), while other scholar considers MS as a critical constituent of dynamic capabilities in the background of identifying opportunities Teece (2007) and Lin and Wang (2015) asserted that sensing capabilities in firms' business ecosystem form the basis for building their dynamic capabilities, including sensing development of science and technology, customer demand, and market segmentation.

MS refers to the ability of a firm to anticipate future evolution of markets and detect emerging opportunities based on information collected from its business ecosystem (Mu, 2015).

According to Bailey (2014) when investigating the aspects of MS there is a clear link to market learning theory and organizational learning which divided into information acquisition, information dissemination, and shared interpretation.

MS allows shifting from management under uncertainty into a structured risk analysis process, avoiding potential losses and achieving superior results, thus MS capability helps a firm to be attentive and watchful to market trend and opportunity discovery (Mu, 2015).

Therefore, MS focus on information about customers, competitors, events and changes in the business environment to gain market intelligence through sense and sensemaking to conduct strategic course of action. MS capability is one kind of sensing capabilities, which involves the capabilities of gathering and filtering market information from outside and inside the firm, determining its meaning, and drawing implications for action that can reduce commercialization process uncertainty and increase opportunities for successful commercial innovation (Lin and Wang, 2015).

\subsection{Dimensions of MS}

Scholars have generally operationalized MS as a multi-component construct as classified in Table 1.

Therefore, in arranging to develop an integrative MS capability, this research follows the construct of MS that developed by Day (1994) and other researchers for example Moorman (1995), Choo, (2001), and Lankinen et al. (2007); have strongly built on this original work. In addition this study focus on resources and capabilities which are systematic, thoughtful, and anticipatory in marketoriented firms. Thus this study proposed three component, sense, sensemaking, and response for MS construct as developed by Day, (1994) and adopted by Lindblom et al. (2008). Table 1 presents the classification of MS and the following is the subsections of MS construct.

Table 1: MS classifications

\begin{tabular}{|c|c|c|}
\hline Author(s) & Approach & Dimensions of MS \\
\hline $\begin{array}{l}\text { Kohli and Jaworski } \\
\text { (1990) }\end{array}$ & Information & Intelligence generation, intelligence dissemination, and organization wide responsiveness \\
\hline Huber (1991) & Information & Obtain information, disseminate information, and use market knowledge \\
\hline Thomas et al. (1993) & Resource & Scanning, Interpreting, and action \\
\hline Day (1994) & Capabilities & Sense, sensemaking, response \\
\hline Moorman (1995) & Information & $\begin{array}{c}\text { Information acquisition, information transmission, conceptual utilization, and instrumental } \\
\text { utilization }\end{array}$ \\
\hline Choo (2001) & Information & Information needs, Information seeking, and Information use \\
\hline Foley and Fahy (2004) & Capabilities & $\begin{array}{c}\text { Learning orientation, Organization system, Marketing information, and Organization } \\
\text { communication }\end{array}$ \\
\hline Lankinen et al. (2007) & Information & Collecting information, disseminating information, and using information \\
\hline Lindblom et al. (2008) & Capabilities & Sense, sensemaking, response \\
\hline Hou (2008) & Capabilities & Sensing, absorptive, integrative, and innovative \\
\hline Day (2011) & Capabilities & Dynamic, and Adaptive \\
\hline
\end{tabular}




\subsubsection{Sensing}

Sensing refers to acquirement of information on different channel members like consumers and competitors beside others (Lindblom et al., 2008). According to Bailey (2014) the element of sensing involves scanning, searching and exploration in dynamic markets, and defined as the collection and distribution of information about the customer, competitors, and relationships in the market. Moreover Hou (2008) defined sensing as a firm's ability to sense the needs of its customers and the dynamics of market better than its rivals.

\subsubsection{Sensemaking}

Lindblom et al. (2008) addressed that sensemaking concern with the interpretation of collected information against ancient practices and knowledge. Sensemaking is the process in which one engages to understand and deal with change effectively, and assists the individual in making sense of changes and also to integrate new experiences into existing frames of reference (Toit, 2007). Sensemaking is also the mechanism by which an individual attributes meaning to events (Ivanova and Torkkeli, 2013).

According to Colville and Pye (2010) sensemaking is concerned with the way people make bets on what is going on and what to do next by way of (inter) action. Sensemaking is also about giving meaning to events and situations (Sharifi and Zhang, 2009). The concept of sense-making is defined by Weick (1995) as a process of making sense and assigning meaning to events in the environment. Similarly Kjærgaard and Vendelø (2015) defined sense-making as: "the process through which people work to understand issues or events that are novel, ambiguous, confusing, or in some other way violate expectations".

\subsubsection{Response}

Response refers to the use of the generated and interpreted information in managerial practices. In other words, response is the process of transforming knowledge and the intangible information into noticeable marketing strategy (Lindblom et al., 2008). Likewise Wei and Wang (2011) believed that "Responsiveness is the action taken in response to intelligence that is generated and disseminated." In this context Moorman (1995) confirmed that the information utilization process refers to the extent to which an organization directly or indirectly applies the acquired and transmitted market information to influence marketing strategy-related actions.

According to Wei and Wang (2011) organizational responsiveness defined as the extent to which a firm responds to market changes, and it results from a firm's proactive interaction with its external environment. The effective organizational action in response to strategic issues often depends on the ability to implement decisions based on scanning strategies and subsequent interpretation of strategic information (Thomas et al., 1993).

\subsection{Internal information dissemination}

Information dissemination is the horizontal and vertical sharing of information within the organization. Horizontal dissemination occurs across functions or units at the same level in the organization structure, while vertical dissemination occurs across levels of the structure. Basically, information dissemination should lead to more generally based learning within the organization.

Internal information disseminations refer to communications between different departments and between managers and employees (Gounaris, 2006). Similarly, Lings and Greenley (2010) specified that information dissemination between management and employees and among managers relates to information generated internally about the needs of employees, and their requirements, which is shared and communicated across departments.

The internal communications is firstly aimed to communicate the organization's goals and marketing strategies to employees and secondly is for managers to understand their employees' needs. A closer interaction between managers and employees, will enables managers to be more aware of employees' needs. Thus managers inside an organization maintain smooth communications with employees and keep employees' attitudes and behaviors in line with the organization's goals, employees will accept the assigned tasks and change their behaviors more quickly (Fang et al., 2014).

\subsection{Innovation}

In today's global markets innovations are considered to be the basis of inevitable changes (Giniuniene and Jurksiene, 2015). Innovation refers to invention and exploitation of useful and novel offerings (Rubio and Marin, 2015). Similarly, innovation means a strategic understanding based on adopting a new tool, policy, program, process, product or service which are produced internally or produced from external resources and may be considered as new in the organization (Tutar et al., 2015). According to Wang and Chung (2013) successful innovations often provide a competitive edge in changing the relative position of a firm within an industry. Innovation plays a crucial role in ensuring the creation of economic activities (Chen et al., 2016). By integrating innovation with MO, a firm with a customer focus can take a more proactive perspective in innovation by meeting market responses, or customer needs (Wang and Chung, 2013).

According to Tutar et al. (2015) the first answer that comes to mind about how competitive advantage or superiority can be achieved is that if firms carefully analyze market dynamism and 
display market-oriented, high entrepreneurial tendency and innovative strategy or strategic innovation, they may maintain their assets and competitive advantages.

Today, in the intensely competitive environmental conditions, firms need to develop less bureaucratic and more flexible innovative strategies in order to adjust to market dynamism (Tutar et al., 2015). Services marketing researchers establish that innovation benefits firms in multiple ways and that innovating services to match customers' needs increases the attractiveness of the firms' offerings (Nguyen et al., 2016).

\subsection{Market performance}

Market performance refers to the company's ability to satisfy, develop, and retain customers by offering products, services, and other elements that suit their needs (Leonidou et al., 2013). In accordance with Nguyen et al. (2016) a superior market performance requires not only information on customers, but also, to proactively implement innovative activities such as organizational learning, orientation towards markets, and internationalization efforts.

According to Wang et al. (2015) Market performance can be seen in terms of new product launches, market development and penetration, quality improvement, and customer satisfaction. However, in this study market performance is conceptualized as the firm's ability to launch new product, provide and develop new product, set reasonable price to product or service, and market share.

\section{Theoretical background and hypothesis development}

The increasing level of market dynamics drives competition on innovation and new product introduction to new levels (Najafi-Tavani et al., 2016). A strong MO facilitates innovation by providing a supportive environment that enhances creativity, a tolerance for risk-taking, and an ability to identify novel opportunities (Song et al., 2015). Dynamic capability DC theory gives details and supports this approach to competitiveness, proposing a new variety of capabilities to put into practice new strategies and to make appropriate use of their limited resources (Najafi-Tavani et al., 2016). According to Barney (2014) the resource-based view (RBV) and knowledge-based view (KBV), firms' acquired possession of unique knowledge is the main source of innovation that leads to certain firms outperforming others (Nguyen et al., 2016).

Although DCs involve complex sets of knowledge and skills, which play a coordinating and interfunctional role to reflect the emergent circumstances and reconfigure organizational resources and capabilities; therefore DC theory posits that possession of such capabilities can differentiate firms in the competition from their rivals (NajafiTavani et al., 2016).

According to Najafi-Tavani et al. (2016) one kind of such capabilities is MO strategies of the firm, come up to generation and dissemination of market intelligence propose that MO requires complementing market-relating organizational capabilities to enable firms to respond to the market intelligence they generate. Building on the theoretical ground, the conceptual framework as in Fig. 1 aims to take on an empirical research on the subject. This model proposes that internal information generation moderate the relationship between MS and innovation, furthermore it expects that innovation mediate the exchange of MS and market performance.

\subsection{MS and market performance}

In literature a number of scholars (Day, 1994; Everett, 2014; Foley and Fahy, 2004; Lings et al., 2009; Lindblom et al., 2008; Bailey, 2014), beside others, are discussed the market sensing concept and most of them indicates that MS capability is important in developing market focus to enhance the organizational performance. For example, in learning firms Day (1994) proposed that a variety of MS information processes is a critical input to new product activities.

This means that the development processes of effective new product engages incessant information sharing and utilization. In a same vein Bailey (2014) stated that firms competing in low-income market should carry out activities to build their market sensing abilities to better adapt to unique market and overcome the challenges and obstacles related to the lack of information and understanding of this low-income market in order to improve their performance. As justification of the market information processes on performance Jaworski and Kohli (1993) provided evidence that MO, which reflects several information processes have appositive influence on overall firm performance (Moorman, 1995).

Drawing on traditional resource-based theory, the literature posits that firms with superior MO achieve superior business performance because they have a greater understanding of customers' expressed wants and latent needs, competitor capabilities and strategies, channel requirements and developments, and the broader market environment than their rivals (Hult and Ketchen, 2001; Jaworski and Kohli, 1993). This represents a 'know-what' advantage that enables the firm to be both more effective and efficient by allowing managers to select the most productive available resource combinations to match market conditions (Slater and Narver, 1995). For these reasons, the study expects that:

H1: The firm's MS has a positive relation with firm's market performance. 


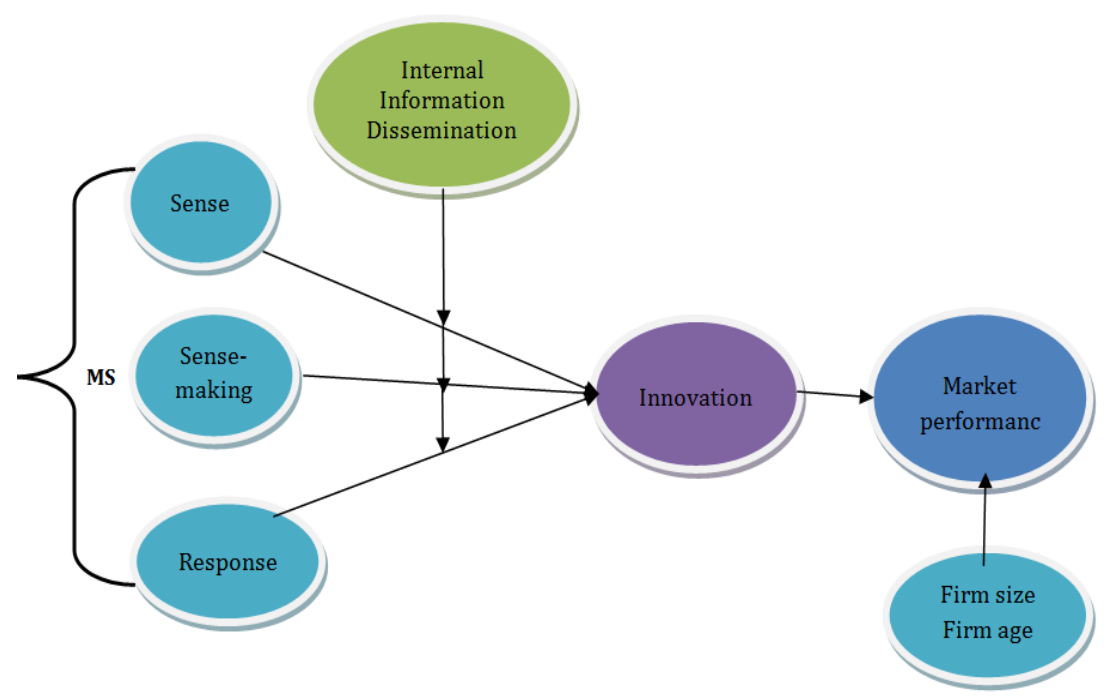

Fig. 1: The conceptual framework

\subsection{MS and innovation}

Generating information from different sources like the marketplace, competitors, and customers may help the firm to be familiar with the value of new information connected to forces of change in the environment to recognize market opportunities and implementing innovation actions (Wei and Wang, 2011). Therefore MS enables firms to improve their development of organizational capabilities because of their greater market information acquisition and utilization (Chen et al., 2012). Firms need strong and current market intelligence in their approaches and mechanisms to improve their marketing capabilities (Najafi-Tavani et al., 2016). In response Nguyen et al. 2016) demonstrated that for high-tech service firms, MO is a critical factor, necessary to create an optimal environment for brand innovation and for facilitating a firm's innovativeness. Similarly Lin and Wang 2015) argued that MS capability also strongly supports firm innovation performance. Likewise Wang and Chung (2013) considered MO as an antecedent of innovation because it is typically involved with doing something new in response to market conditions. Thus:

H2: The firm's MS has a positive relation with firm's innovation capability.

\subsection{Innovation and market performance}

Research shows that innovations transform existing markets, increase financial growth, and is an important element in firms' search for sustainable competitive advantage (Nguyen et al., 2016). According to Tutar et al. (2015) there has been a significant interest among scholars on the role of innovation capability in achieving superior market performance (Li and Mitchell, 2009; Rosenbusch et al., 2011; Sok et al., 2013).

Successful innovation not only helps a firm achieve a competitive advantage, it also makes a significant contribution to the firm's survival, and its growth as well as financial success (Song et al., 2015). Innovation is a core driving force that allows for the creation of new opportunities and markets (Nguyen et al., 2016). In their paper Tutar et al. (2015) have found a positive relation between innovation and market performance.

According to Hao et al. (2012) usually, in almost all research level, the innovation is important factor on performance that proved by Johnston (2003), strategy innovation is aimed at growing your top line, achieving new levels of performance and success. The managerial innovation and technological innovation are different in their effect on performance (Hao et al., 2012).

Summing up previous arguments, innovators have the potential to create markets, shape customer preferences, and even change the basic behavior of consumers, which leads to higher profits (DiazFernandez et al., 2015). Thus this study posits that:

H3: The firm's innovation capability has a positive relation with firm's market performance.

\subsection{The mediating role of innovation}

From an organizational viewpoint, innovation is generally conceptualized as the successful foreword of a new thing or method or embodiment, mixture, or synthesis of knowledge in original, relevant, valued new products, procedures, or services (Hao et al., 2012). According to Tutar et al. (2015) innovation capabilities play a key role between strategic orientation and market performance. Likewise Hao et al. (2012) innovation is the critically mediate path of Organizational structure on performance.

On the other hand, Tutar et al. (2015) discussed the effect of strategic orientation on innovation capabilities and market performance. Similarly Giniuniene and Jurksiene (2015) examined the mediating role of innovation and organizational learning in the relationship between dynamic 
capabilities and firm performance. Other research suggests that the effect of MO on performance is not direct, but instead is via innovation (Wang and Chung, 2013). Bearing in mind the above mentioned this study posit that:

H4: The innovation capability mediates the relationship between market sensing and market performance.

\subsection{The moderating role of internal information generation}

Executives offer a significant amount of their time to picking up information signals from their organizations internal and external environments, because Information use in general has the effect of reducing feelings of uncertainty and increasing the sense of confidence in executives through effective determining the opportunities and threats (Sund, 2013). However, when conflicts arise internally at the time of environmental scanning, MO or MS, such as task conflict and relationship conflict, it may be more difficult for the firm to make a decision to respond to the environment (Wei and Wang, 2011).

In contrast, high market information sharing which defined as the dissemination of marketrelated information between departments (Rodrigues and Pinho, 2012), may not only reduce different conflicts but also create a common understanding among decision makers (Wei and Wang, 2011), and makes the firm's employees are more likely to be able to effectively respond to environmental changes. Although A high level of IMO in which internal information dissemination included indicates an organization's commitment to understanding and responding to the needs of employees and thus reflects an effective relationship between the organization and its employees. In this context internal information dissemination leverage an organization with significant contribution and backdrop that can help in the explanation of the information sourced from organization's environment and consequently interacts and integrates the role of MS on innovation capability. Therefore:

H5: The effect of market sensing on innovation capability is stronger when internal information dissemination is higher.

\section{Method}

\subsection{Sample and data collection}

This study collect data for testing the hypotheses via questionnaire survey of firms that located in three towns represents the capital of Sudan, where convenient sample and self-administrated survey was used to distribute 200 questionnaires to be filled by one of the top or middle managers of the sampling border in 200 firms. A professional translation to questionnaire was firstly conducted from English into Arabic and back to English. Subsequently, a number of researchers in the same field assessed the correctness and the clearance of questions and measurement items. A sample of questionnaire was secondly developed and sent to four professional academicians to reduce concern regarding the face validity of measures. Several alterations to question wording, modification of items, as well as the format and esthetics of the questionnaire were made for clarity. In stage three, pre-test was conducted upon fifty copies of the surveys distributed to the firms randomly; it reveals that the values of Cronbach's Alpha test for the variables fall above the 0.70 , these variables have an acceptable level of reliability (Sekaran, 1992). The survey started on the 1rst of March 2015 and by the end of April 2015 a total of 166 out of 200 questionnaires received from respondents, the overall response rate was $85.5 \%$ this was considered as high rate due to questionnaires given one by one to respondents and in researches used a selfadministrated survey (Sekaran, 1992). Those who didn't responded to fill the questionnaire some were mentioned that they were not authorized to fill the questionnaires while others were not transparent in their justifications. Based on the descriptive statistics using the frequency analysis shows that (91\%) of the respondent are male, where (9\%) female. With regard to respondents age $(15 \%)$ are young with less than 30 years, while the others ranged $30-50$ are (64\%), those from 51 to 60 are $(14 \%)$, and above 60 years are (7\%). In term of their job title (10\%) are general manager, (9\%) are branch manager and deputy (9\%), where $(72 \%)$ are department manager. Concerning the academic qualification (3\%) secondary, (58\%) Graduate and $(39 \%)$ is post graduate. Regarding their years of experience (38\%) are 10 years and less, those ranged from 11 to 20 is (40\%), where above 21 years was (22\%). Regarding the responded firms Table 2 presents the general characteristics of firms under the study.

\subsection{Measures}

This paper employed 5-point Likert scale for all measures, ranging from "strongly disagree" to "strongly agree". Measures used in this study adopted and generated from available previous studies. MS was conceptualized as continuous ability to learn about the market (Day, 2002). Based on Lindblom et al. (2008), this paper measured MS with11 items through multidimensional construct to include sense, sensemaking, and response. However the three dimensions of MS was loaded into two dimensions, sense-making and response as a result the model was modified as shown in Fig. 2. Innovation capability was conceptualized as invention and exploitation of useful and novel offerings (Rubio and Marin, 2015). In this paper innovation was measured on multi-items scales through a unidimensional approach adopted from 
(Panayides, 2006). Similarly internal information dissemination was conceptualized as the communications between different departments and between managers and employees (Gounaris, 2006).

Based on Kohli and Jaworski (1990) and Lings and Greenley (2010) this paper measured internal information dissemination on multi-item scale adopted from (Ruizalba et al., 2014). Finally market performance was measued in this paper on multiitem scale adapted from Grønholdt and Martensen (2006) through a unidimensional approach.

Table 2: Responded firms profile

\begin{tabular}{|c|c|c|c|c|c|}
\hline category & $f$ & $\%$ & category & $f$ & $\%$ \\
\hline Nature of work & & & The firms number of competitors & & \\
\hline Commercial & 53 & 32 & Less than 5 competitors & 26 & 16 \\
\hline Agricultural & 2 & 1 & $5-10$ & 56 & 34 \\
\hline Industrial & 87 & 52 & More than 10 competitors & 81 & 49 \\
\hline Services & 24 & 15 & No competitors & 1 & 1 \\
\hline The firm age & & & The firm products & & \\
\hline Less than 5 years & 22 & 13 & Consumption & 60 & 35 \\
\hline 5 to 15 years & 60 & 36 & Industrial & 57 & 35 \\
\hline More than 15years & 84 & 51 & Service & 48 & 29 \\
\hline Markets the firm works in & & & Agricultural & 1 & 1 \\
\hline Local & 92 & 56 & Number of employees & & \\
\hline International & 2 & 1 & Less than 50 & 45 & 27 \\
\hline Local and International & 71 & 43 & $50-100$ & 30 & 18 \\
\hline The firm ownership & & & $101-150$ & 19 & 12 \\
\hline Sudanese ownership & 124 & 75 & More than 150 & 72 & 43 \\
\hline Multinational ownership & 26 & 16 & & & \\
\hline Owned by other country & 15 & 9 & & & \\
\hline
\end{tabular}

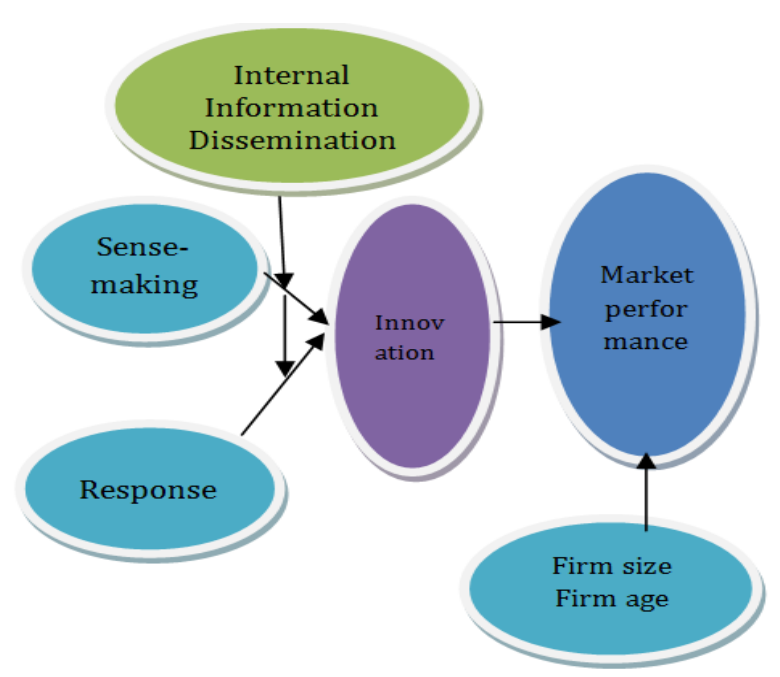

Fig. 2: The modified conceptual framework

\section{Results and discussion}

Composite reliability assesses inter-item consistency, which was operationalized with the internal consistency method estimated by Cronbach's alpha (Chen et al., 2015). This study shows that the average values of rooted square (AVEs) of the main constructs (MS, innovation, information dissemination, and market performance) were greater than their correlations with any other constructs in the study. Principle component analysis, with varimax rotation and latent root criterion (eigenvalue $>1$ ) was used. As recommended by Hair et al. (2010), the factor analysis domenstrated that (KMO) measure of sampling adequacy for all variables exceeded 0.6, Bartlett's test of sphericity was significant at 0.05 , communalities of items greater than 0.50 , and the minimum requirement of factor loading 0.50 , with value of cross loading exceeds 0.50 .

Table 3 displays the variables, factor loadings, eigenvalues, and percentage of variance explained by the factors. On the other hand reliability coefficients of 0.70 or higher are considered adequate (Chen et al., 2015). The descriptive statistics and reliability test showed in Table 4 demonstrated that alpha for all the dimensions fall above 0.70 . Therefore, it can be concluded that the measures have acceptable level of reliability.

A hierarchical regression analysis was conducted to test hypotheses. Results showed that all of the VIF values as recommended by Hair et al. (2010) are much lower than the cut-off value of 2, indicating multicollinearity is not a problem in this study.

Table 5 presents the regression analysis results for testing the relationship between MS and market performance, this relationship controlled by two variables (firm size, and firm age). The results reveals that the two regression models were significant $(F=11.47, p<0.01 ; F=25.30, p<0.01)$.

The first model shows that the two control variables were significant on market performance and together explains $13.9 \%$ of the total variation in market performance. The addition of the two MS components in the second model explains $42 \%$ of variance in market performance. The accumulation of both control variables and the MS components explains $56 \%$ of the variance in market performance. Further analysis for the outcomes in Table 5 showed that there is significant relationship between response and market performance $(\beta=.460, p<0.001)$ H1.2, while H1.1 the relationship between sensemaking and market performance was not significant $(ß=.138, p>0.05)$. These results give partial support to hypothesis $\mathrm{H} 1$ which states that there is a positive relationship between MS and market performance. Similarly, the results of regression for how the predictive of the MS construct and its dimension's effects towards innovation capability controlled by two variables (firm size and firm age) are also presented in Table 6. 
The results indicate that the two regression models were significant $(\mathrm{F}=7.30, \mathrm{p}<0.01 ; \mathrm{F}=36.72$, $\mathrm{p}<0.01$ ). The first model shows that the two control variables were significant on innovation capability and explains $9 \%$ of the total variation in innovation. The addition of the two MS components in the second model explains $51 \%$ of variance in innovation. This means that the summing up of control variables and the market sensing components explains $60 \%$ of the variance in innovation.

Extra analysis of the results in Table 6 showed that response have the most significant relationship on innovation capability $(ß=4.33, \mathrm{p}<0.01) \mathrm{H} 2.2$, followed by H2.1 the relationship between sensemaking and innovation capability $(ß=3.20$, $\mathrm{p}<0.01)$. These results give full support to hypothesis $\mathrm{H} 2$ which states that there is a positive relationship between MS and innovation capability.

Table 3: factor analysis

\begin{tabular}{|c|c|c|c|c|}
\hline Construct & Variables/items & Factor loading & Eigenvalues & PEV \\
\hline IMO & Inf. Dissemination & & 1.18 & 11.84 \\
\hline $\mathrm{KMO}=.830$ & ID1 & .792 & & \\
\hline TVE $=68.993$ & ID2 & .779 & & \\
\hline \multirow[t]{3}{*}{$\mathrm{BTS}=681.497$} & ID3 & .720 & & \\
\hline & ID4 & .661 & & \\
\hline & ID5 & .541 & & \\
\hline MS & Sensemaking & & 5.61 & 56.12 \\
\hline $\mathrm{KMO}=.897$ & Sen1 & .796 & & \\
\hline $\mathrm{TVE}=69.451$ & Sen2 & .786 & & \\
\hline \multirow[t]{9}{*}{$\mathrm{BTS}=958.045$} & Sen3 & .752 & & \\
\hline & Sen4 & .746 & & \\
\hline & Sen5 & .724 & & \\
\hline & Sen6 & .708 & & \\
\hline & Response & & 1.33 & 13.34 \\
\hline & Res1 & .862 & & \\
\hline & Res2 & .828 & & \\
\hline & Res3 & .811 & & \\
\hline & Res4 & .703 & & \\
\hline Org. Capabilities & innovation & & 1.17 & 15.87 \\
\hline $\mathrm{KMO}=.900$ & Inn1 & .753 & & \\
\hline TVE $=62.258$ & Inn2 & .628 & & \\
\hline \multirow[t]{3}{*}{$\mathrm{BTS}=1551.199$} & Inn3 & .597 & & \\
\hline & Inn4 & .567 & & \\
\hline & Inn5 & .521 & & \\
\hline Marketing performance & Market performance & & 4.572 & 50.799 \\
\hline $\mathrm{KMO}=.851$ & Mp1 & .827 & & \\
\hline TVE = 63.232 & Mp2 & .813 & & \\
\hline \multirow[t]{4}{*}{$\mathrm{BTS}=644.324$} & Mp3 & .679 & & \\
\hline & Mp4 & .673 & & \\
\hline & Mp5 & .618 & & \\
\hline & Mp6 & .556 & & \\
\hline
\end{tabular}

Table 4: Correlation, descriptive statistics and reliability test

\begin{tabular}{|c|c|c|c|c|c|c|}
\hline No & Variables & 1 & 2 & 3 & 4 & 5 \\
\hline 1 & Info- diss & 1 & & & & \\
\hline 2 & Sensemaking & $.530 * *$ & 1 & & & \\
\hline 3 & Response & $.477^{* *}$ & $.626^{* *}$ & 1 & & \\
\hline 4 & Innovation & $.583^{* *}$ & $.622^{* *}$ & $.587^{* *}$ & 1 & \\
\hline \multirow[t]{4}{*}{5} & M. performance & $.411^{* *}$ & $.468^{* *}$ & $.578^{* *}$ & $.580^{* *}$ & 1 \\
\hline & Mean & 4.26 & 4.07 & 4.17 & 3.98 & 4.24 \\
\hline & S. deviation & .674 & .755 & .706 & .727 & .623 \\
\hline & Reliability & .830 & .898 & .858 & .800 & .849 \\
\hline
\end{tabular}

Table 5: Effect of market sensing on market performance

\begin{tabular}{ccc}
\hline Variables & Beta 1 & Beta 2 \\
\hline Control variables & & \\
Firm size & $.362^{* * *}$ & $.247^{* * *}$ \\
Firm age & $-.229^{* * *}$ & -.072 \\
Model variables & & \\
Sensemaking & & .138 \\
Response & & $.460^{* * *}$ \\
F value & $11.47^{* * *}$ & $25.30^{* * *}$ \\
$\mathrm{R}^{2}$ & .139 & .420 \\
AdjustedR & .127 & .403 \\
$\mathrm{R}^{2}$ change & .139 & .281 \\
F change & $11.470^{* * *}$ & $33.832^{* * *}$ \\
\hline \multicolumn{2}{c}{ Note: level of significant: ${ }^{* * *} \mathrm{p}<0.01$}
\end{tabular}

For testing the relationship between innovation and market performance controlled by the two variables (firm age and firm size) Table 7 presents the two regression models were significant $(\mathrm{F}=$
10.138, $\mathrm{p}<0.01 ; \mathrm{F}=29.32, \mathrm{p}<0.01)$. The first model shows that the two control variables were significant on market performance and explains $11 \%$ of the total variation in market performance. The innovation in the second model explains 37\% of variance in market performance. The summation of control variables and innovation explains $48 \%$ of the variance in market performance.

Also Table 7 shows significant relationship between innovation and market performance, thus H3 was supported. The innovation capability was hypothesized to mediate the relationship between the MS and market performance.

However, in accordance with result of regression analysis presented in Table 8 the two control 
variables in first step, have significant effect on market performance.

Table 6: Effect of market sensing on innovation

\begin{tabular}{ccc}
\hline Variables & Beta 1 & Beta 2 \\
\hline Control variables & & \\
Firm size & $.288^{* * *}$ & .115 \\
Firm age & $-.191^{* *}$ & -.032 \\
Model variables & & $.320^{* * *}$ \\
Sensemaking & & $.433^{* * *}$ \\
Response & $7.306^{* * *}$ & $36.722^{* * *}$ \\
F value & .093 & .512 \\
$\mathrm{R}^{2}$ & .081 & .498 \\
AdjustedR & .093 & .419 \\
$\mathrm{R}^{2}$ change & $7.306^{* * *}$ & $60.060^{* * *}$ \\
$\mathrm{~F}^{*}$ change &
\end{tabular}

Table 7: Effect of innovation on market performance

\begin{tabular}{ccc}
\hline Variables & Beta 1 & Beta 2 \\
\hline Control variables & & \\
Firm size & $.325^{* * *}$ & $.193^{* * *}$ \\
Firm age & $-.192^{* *}$ & -.075 \\
Model variables & & \\
Innovation & & $.527^{* * *}$ \\
F value & $10.138^{* * *}$ & $29.322^{* * *}$ \\
$\mathrm{R}^{2}$ & .119 & .371 \\
AdjustedR $^{2}$ & .107 & .359 \\
$\mathrm{R}^{2}$ change & .119 & .252 \\
F change & $10.138^{* * *}$ & $59.748^{* * *}$ \\
\hline \multicolumn{2}{c}{ Note: level of significant: ${ }^{* *} \mathrm{p}<0.05,{ }^{* * *} \mathrm{p}<0.01$}
\end{tabular}

The control variables explain about $14 \%$ of the variance in market performance. In the second step, the results showed that sense-making was not significantly influenced market performance $(ß=.135, p>0.05)$, while response was significantly influenced market performance $(\beta=.450, p<0.001)$. In step three only response was significantly influenced market performance $(\beta=.354, p<0.01)$, while the relationship between innovation and market performance in step three was significant. This result could be interpreted that innovation capability is partially mediated the relationship between response and market performance. Hence H4 was partially supported.

As for the prediction of how the information dissemination moderates the relationship between MS and innovation controlled by the two variables (firm age and firm size) Table 9 shows the regression results for the moderating effect of internal information dissemination in this relationship. The results showed that the $\mathrm{F}$ change is significant in all steps except step four and the information dissemination moderate the relationship between the two components of MS (sense-making: $\beta=.266, p<0.01$; response: $\beta=.263$, $\mathrm{p}<0.01$ ) and innovation.

Table 8: The mediating role of innovation in market sensing to market performance relationship

\begin{tabular}{cccc}
\hline \multicolumn{3}{c}{ variable } & \multicolumn{2}{c}{ DV: Market performance } \\
\hline Control variables: & & Model2 & Model3 \\
Firm size & $.365^{* * *}$ & $.246^{* *}$ & $.213^{* *}$ \\
Firm age & $-.225^{* *}$ & -.073 & -.049 \\
Independent variables: & & & \\
Sensemaking & & .135 & .003 \\
Response & & $.450^{* * *}$ & $.354^{* * *}$ \\
Mediating variable: & & & $.328^{* * *}$ \\
Innovation & $11.575^{* * *}$ & $23.500^{* * *}$ & $23.758^{* * *}$ \\
F value & .144 & .409 & .468 \\
R ${ }^{2}$ & .131 & .391 & .448 \\
Adjusted R ${ }^{2}$ & .144 & .477 & .454 \\
$\mathrm{R}^{2}$ change & $11.575^{* * *}$ & $30.481^{* * *}$ & $15.065^{* * *}$ \\
F change & \multicolumn{2}{c}{}
\end{tabular}

The introduction of the interaction terms in step four explains insufficient value of variance (.007) in innovation and the model as a whole was significant ( $\mathrm{F}=26.203$, p<0.01). However information dissemination shows no moderating effect in the relationship between MS and innovation. Following the procedures implemented in Chow et al. (2015) for plotting the interaction effect to examine the relationship between sense-making and market performance the pattern of interaction effect as shown in Fig. 3 indicates that information dissemination dampens the positive relationship between sense-making and innovation. This means that in the low range of information dissemination the relationship between sense-making and innovation is positive, while in high range the relation is negative. Thus H5.1 was not supported.

Table 9: The moderating role of information dissemination in market sensing to innovation relationship

\begin{tabular}{ccccc}
\hline \multicolumn{5}{c}{ Variables DV: Innovation } \\
\hline & Model 1 & Model 2 & Model 3 & Model 4 \\
Control variables: & & & & \\
Firm size & $.271^{* * *}$ & .101 & .104 & .097 \\
Firm age & $-.216^{* * *}$ & -.070 & -.059 & -.053 \\
Predicting variables: & & & & \\
Sensemaking & & $.387^{* * *}$ & $.266^{* * *}$ & .971 \\
Response & & $.337^{* * *}$ & $.263^{* * *}$ & -.335 \\
Moderating variable: & & & & \\
Information dissemination & & & & .381 \\
F value & $7.302^{* * *}$ & $32.225^{* * *}$ & $36.238^{* * *}$ & $26.203^{* * *}$ \\
$\mathrm{R}^{2}$ & .092 & .476 & .562 & .569 \\
Adjusted R & .079 & .461 & .547 & .547 \\
$\mathrm{R}^{2}$ change & .092 & .384 & .087 & .007 \\
F change & $7.302^{* * *}$ & $52.977^{* * *}$ & $27.885^{* * *}$ & 1.051 \\
\hline \multicolumn{5}{c}{ Note: level of significant: ${ }^{* *} \mathrm{p}<0.05,^{* * *} \mathrm{p}<0.01$} \\
\hline
\end{tabular}

Also Fig. 4 presents the pattern of interaction effect for the relationship between response and market performance, this pattern shows that information dissemination strengthens the positive relationship between response and innovation. This indicates that in the high range of information dissemination the relationship between response and innovation is positive, while in low range the 
relationship is negative. Hence, H5.2 was supported and generally $\mathrm{H} 5$ was partially supported.

Regarding the discussion this study thought to answer the question of, does internal information dissemination moderates the relationship between MS and innovation capability to enhance market performance? The findings provide five valuable contributions to the literature as a result. First, this study empirically proves new relationships in an integrative model demonstrating the positive relationship between MS and market performance. Second, the findings also indicates a positive significant relationship between MS and innovation, confirming the (Lin and Wang, 2015) argues that market sensing capability is strongly supports firm innovation performance and (Wang and Chung, 2013) consideration of market orientation as an antecedent of innovation.

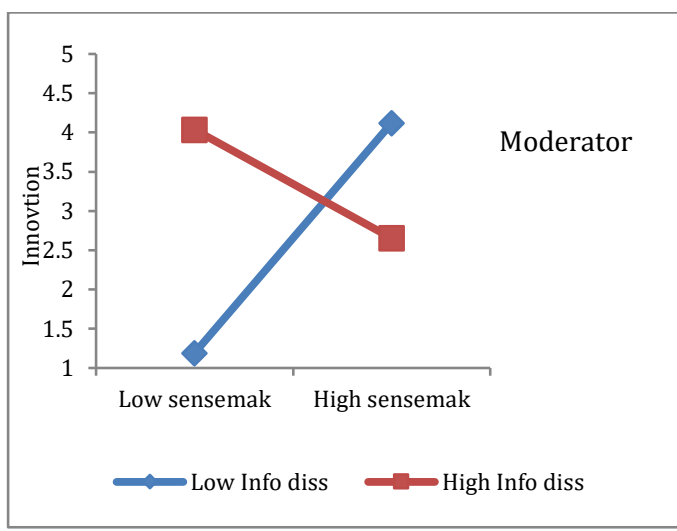

Fig. 3: The moderating role of information dissemination in sense-making to innovation relationship

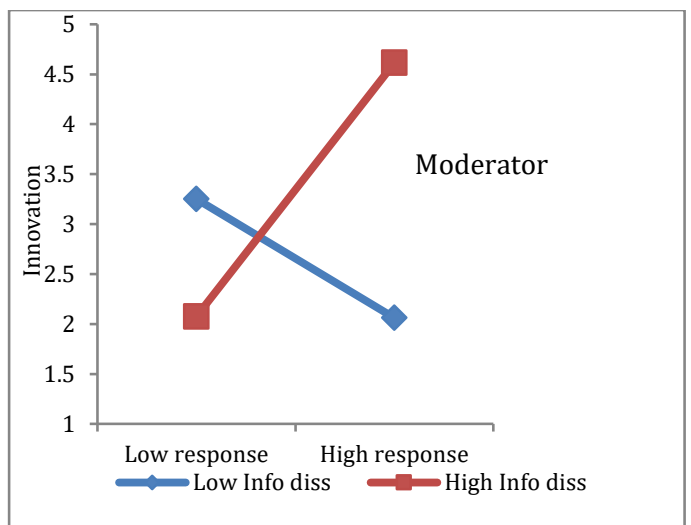

Fig. 4: The moderating role of information dissemination in response to innovation relationship

Third, another attractive pattern among the variables is that the positive relationship between innovation and market performance extends the significant interest among scholars in the role of innovation capability in driving market performance (Tutar et al., 2015). Fourth, the result shows that innovation was partially mediate the relationship between market sensing and market performance through the interplay between MS and innovation to investigate how performance is achieved; this confirms the result obtained by Ardyan (2016) who indicates that product innovativeness success mediates the relationship between MS and SMEs performance. These findings are contributing to the resource based theory and dynamic capability by bringing forward MS to extend and statistically examine new relationships to comprehend innovation and market performance antecedents. Fifth, information dissemination's moderating effect on the relationship between MS and innovation is not statistically significant, thus it does not influence the effect of sense-making on innovation. Accordingly, given their level of information dissemination firms can manage innovation on the foundation of their MS level. However, the finding that information dissemination strengthens the positive relationship between response and innovation suggests that firms with a high response to MS can benefit more from a high level of information dissemination than those with a low level. Although strong information dissemination allows firms to rapidly and accurately gather and interpret market knowledge and to recognize opportunities corresponding their innovation, thereby enhancing them to realizes higher market performance. This result is in line with social exchange theory in explaining and forecasting variance in innovation in the middle of firms. In particular, the result shows that innovation is more responsive to the benefit derived from response to MS and the high range of information dissemination.

\section{Conclusion}

This study explored the precursors for enhancing market performance exhibited by firms through the theoretical lens of resource based and dynamic capability theory. In doing so the findings identify that MS and innovation are the most important drivers for enhancing market performance of the firms. Findings also demonstrate that firms can develop exchange relationship with their employees that, in turn leads to enhance higher levels of market performance because of an obligation to reciprocate. As such the study contributes to the social exchange literature by illustrating the complementary nature of social exchange relationships in examining the interplay effect of MS and internal information dissemination on innovation. This is reflected by the interaction effect of internal information dissemination on the relationship between sensemaking and innovation, and on the exchange between response and innovation. In attempt to extend MS in proving new relationships this study highlighted the mediating effect of innovation in the exchange between market sensing and market performance.

The results of this study have valuable implications for managerial practice. Firstly, managers must understand the importance of innovation capability that must be involved to translating the adequate market information obtained through MS towards firm's market performance. Second managers need to pay greater attention to the situation under which response to MS and internal information dissemination interacts 
to effect market performance. Third, from managerial point of view the findings obtained from testing the conceptual framework of this study improves the common understanding among decision makers, which makes the firm more likely to be able to effectively respond to environmental changes. Forth, also this study suggests that firms can develop MS as an adaptive tool for innovation and performance to face the business environmental changes. This study has a number of limitations which was taken as an opportunity for future examinations. First, the measures of dependent variable, market performance is conceptualized as the firm's ability to launch new product, provide and develop new product, set reasonable price to product or service, and market share. However in Nguyen et al. (2016) market performance focuses on financial and customer performance. Second, the focus of this study is to examine the moderating effect of information dissemination between MS and innovation, this study was not exploring other possible antecedents to the relationship between innovation and market performance. So, future research has to take this into consideration by examine the moderating effect of information dissemination or any other antecedent in innovation - performance relationship. Third, the study utilized a one-dimensional measure of innovation at the time Nguyen et al. 2016) recommends future studies should examine whether the quality of the innovation (incremental or radical) has any influence on the market performance.

\section{Acknowledgement}

The authors acknowledged the representatives of companies and firms operating in Sudan whom are responded to fill the questionnaire; their valuable time and effort been exerted to make this study valuable.

\section{References}

Ardyan E (2016). Market sensing capability and smes performance: The mediating role of product innovativeness success. Business and Economics Review, 25(2): 79-97.

Bailey CJ (2014). Competing in low-income markets using dynamic and adaptive market sensing capabilities. Gordon Institute of Business Science, University of Pretoria, Pretoria, South Africa.

Barney JB (2014). Howmarketing scholars might help address issues in resource-based theory. Journal of the Academy of Marketing Science, 42(1): 24-26.

Chen H, Li Y, and Liu Y (2015). Dual capabilities and organizational learning in new product market performance. Industrial Marketing Management, 46: 204-213.

Chen KH, Wang CH, Huang SZ, and Shen GC (2016). Service innovation and new product performance: The influence of market-linking capabilities and market turbulence. International Journal of Production Economics, 172: 54-64.

Chen YC, Li PC, and Evans KR (2012). Effects of interaction and entrepreneurial orientation on organizational performance: Insights into market driven and market driving. Industrial Marketing Management, 41(6): 1019-1034.
Choo CW (2001). Environmental scanning as information seeking and organizational learning. Information Research, 7(1): 1-37.

Chow CWC, Lai JY, and Loi R (2015). Motivation of travel agents' customer service behavior and organizational citizenship behavior: The role of leader-member exchange and internal marketing orientation. Tourism Management, 48: 362-369.

Colville I and Pye A (2010). A sensemaking perspective on network pictures. Industrial Marketing Management, 39(3): 372-380.

Day GS (1994). The capabilities of market-driven organizations. Journal of Marketing, 58(4): 37-52.

Day GS (2002). Managing the market learning process. Journal of Business and Industrial Marketing, 17(4): 240-252.

Day GS (2011). Closing the marketing capabilities gap. Journal of Marketing, 75(4): 183-195.

Diaz-Fernandez M, Bornay-Barrachina M, and Lopez-Cabrales A (2015). Innovation and firm performance: the role of human resource management practices. Evidence-based HRM: a Global Forum for Empirical Scholarship, 3(1): 64-80.

Dibrell C, Craig JB, and Hansen EN (2011). How managerial attitudes toward the natural environment affect market orientation and innovation. Journal of Business Research, 64(4): 401-407.

Everett RF (2014). A crack in the foundation: Why SWOT might be less than effective in market sensing analysis. Journal of Marketing and Management, Special Issue, 1(1): 58-78.

Fang SR, Chang E, Ou CC, and Chou CH (2014). Internal market orientation, market capabilities and learning orientation. European Journal of Marketing, 48(1/2): 170-192.

Foley A and Fahy J (2004). Towards a further understanding of the development of market orientation in the firm: a conceptual framework based on the market-sensing capability. Journal of Strategic Marketing, 12(4): 219-230.

Giniuniene J and Jurksiene L (2015). Dynamic capabilities, innovation and organizational learning: Interrelations and impact on firm performance. Procedia-Social and Behavioral Sciences, 213: 985-991.

Gounaris SP (2006). Internal-market orientation and its measurement. Journal of Business Research, 59(4): 432-448.

Grinstein A (2008). The effect of market orientation and its components on innovation consequences: A meta-analysis. Journal of the Academy of Marketing Science, 36(2): 166-173.

Grønholdt L and Martensen A (2006). Key marketing performance measures. The Marketing Review, 6(3): 243-252.

Hair JF, Anderson RE, Babin BJ, and Black WC (2010). Multivariate data analysis: A global perspective. Upper Saddle River, New Jersey, USA.

Hao Q, Kasper H, and Muehlbacher J (2012). How does organizational structure influence performance through learning and innovation in Austria and China. Chinese Management Studies, 6(1): 36-52.

Hou JJ (2008). Toward a research model of market orientation and dynamic capabilities. Social Behavior and Personality: An International Journal, 36(9): 1251-1268.

Huber GP (1991). Organizational learning: contributing processes and the literatures. Organizational Science, 2(1): 88-115.

Hult GTM and Ketchen DJ (2001). Does market orientation matter?: A test of the relationship between positional advantage and performance. Strategic Management Journal, 22(9): 899-906.

Ivanova M and Torkkeli L (2013). Managerial sensemaking of interaction within business relationships: A cultural perspective. European Management Journal, 31(6): 717-727.

Jaworski B and Kohli AK (1993). Market orientation: Antecedents and consequences. Journal of Marketing, 57(3): 53-70. 
Johnston RE (2003). The Power of strategy innovation. AMACOM, New York, USA.

Kjærgaard A and Vendelø MT (2015). The role of theory adaptation in the making of a reference discipline. Information and Organization, 25(3): 137-149.

Kohli AK and Jaworski BJ (1990). Market orientation: The construct, research propositions, and managerial implications. Journal of Marketing, 54(2): 1-18.

Lankinen J, Rökman M, and Tuominen P (2007). Market-sensing capability and market orientation in the food industry: empirical evidence from Finland. In the $19^{\text {th }}$ Nordic Academy of Management Conference, Melbourne, Australia.

Leonidou LC, Leonidou CN, Fotiadis TA, and Zeriti A (2013). Resources and capabilities as drivers of hotel environmental marketing strategy: Implications for competitive advantage and performance. Tourism Management, 35: 94-110.

Li X and Mitchell R (2009). The pace and stability of small enterprise innovation in highly dynamic economies: A chinabased template. Journal of Small Business Management, 47(3): 370-397.

Lin JH and Wang MY (2015). Complementary assets, appropriability, and patent commercialization: Market sensing capability as a moderator. Asia Pacific Management Review, 20(3): 141-147.

Lindblom A, Olkkonen R, Mitronen L, and Kajalo S (2008). Marketsensing capability and business performance of retail entrepreneurs. Contemporary Management Research, 4(3): 219-236.

Lings I, Wilden R, and Gudergan S (2009). The effects of sensing and seizing of market opportunities and reconfiguring activities on the organisational resource base. In the Australian and New Zealand Marketing Academy Conference, Melbourne, Australia: 1-10. Available online at: http://eprints.qut.edu.au/29709/1/29709.pdf

Lings IN and Greenley GE (2010). Internal market orientation and market-oriented behaviours. Journal of Service Management, 21(3): 321-343.

Moorman C (1995). Organizational market information processes: Cultural antecedents and new product outcomes. Journal of Marketing Research, 32(3): 318-335.

Mu J (2015). Marketing capability, organizational adaptation and new product development performance. Industrial Marketing Management, 49: 151-166.

Najafi-Tavani S, Sharifi H, and Najafi-Tavani Z (2016). Market orientation, marketing capability, and new product performance: The moderating role of absorptive capacity. Journal of Business Research, 69(11): 5059-5064.

Nguyen B, Yu X, Melewar TC, and Gupta S (2016). Critical brand innovation factors (CBIF): Understanding innovation and market performance in the Chinese high-tech service industry. Journal of Business Research, 69(7): 2471-2479.

Panayides P (2006). Enhancing innovation capability through relationship management and implications for performance. European Journal of Innovation Management, 9(4): 466-483.

Park HS, Auh S, Maher AA, and Singhapakdi A (2011). Marketing's accountability and internal legitimacy: Implications for firm performance. Journal of Business Research, 65(11): 1576 1582.

Rodrigues AP and Pinho JC (2012). The impact of internal and external market orientation on performance in local public organisations. Marketing Intelligence and Planning, 30(3): 284-306.

Rosenbusch N, Brinckmann J, and Bausch A (2011). Is innovation always beneficial? A meta-analysis of the relationship between innovation and performance in smes. Journal of Business Venturing, 26(4): 441-457.
Rubio A and Marin L (2015). Innovation Management to market performance: The effect of consumer identification in the evaluation of brand extensions. Procedia-Social and Behavioral Sciences, 181: 269-275.

Ruizalba JL, Bermúdez-González G, Rodríguez-Molina MA, and Blanca MJ (2014). Internal market orientation: An empirical research in hotel sector. International Journal of Hospitality Management, 38: 11-19.

Sekaran U (1992). Research methods for business: askill bulding approach. John Wily and Sons, New Jersey, USA.

Sharifi S and Zhang M (2009). Sense-making and recipes: Examples from selected small firms. International Journal of Entrepreneurial Behaviour and Research, 15(6): 555-570.

Slater S and Narver J (1995). Market orientation and the learning organization. Journal of Marketing, 59(3): 63-74.

Sok P, O'Cass A, and Sok KM (2013). Achieving superior SME performance: Overarching role of marketing, innovation, and learning capabilities. Australasian Marketing Journal, 21(3): 161-167.

Song J, Wei YS, and Wang R (2015). Market orientation and innovation performance: The moderating roles of firm ownership structures. International Journal of Research in Marketing, 32(3): 319-331.

Sund KJ (2013). Scanning, perceived uncertainty, and the interpretation of trends: A study of hotel directors' interpretation of demographic change. International Journal of Hospitality Management, 33: 294-303.

Teece DJ (2007). Explicating dynamic capabilities: the nature and microfoundations of (sustainable) enterprise performance. Strategic Management Journal, 28(13): 1319-1350.

Teece DJ, Pisano G, and Shuen A (1997). Dynamic capabilities and strategic management. Strategic Management Journal, 18(7): 509-533.

Thomas JB, Clark SM, and Gioia DA (1993). Strategic sensemaking and organizational performance: Linkges among scanning, interpretation, action. Academy of Management Journal, 36(2): 239-270.

Toit AD (2007). Making sense through coaching. Journal of Management Development, 26(3): 282-291.

Tutar H, Nart S, and Bingöl D (2015). The effects of strategic orientations on innovation capabilities and market performance: The case of ASEM. Procedia-Social and Behavioral Sciences, 207: 709-719.

Wang CL and Chung HF (2013). The moderating role of managerial ties in market orientation and innovation: An Asian perspective. Journal of Business Research, 66(12): 2431-2437.

Wang G, Dou W, Zhu W, and Zhou N (2015). The effects of firm capabilities on external collaboration and performance: The moderating role of market turbulence. Journal of Business Research, 68(9): 1928-1936.

Wei YS and Atuahene-Gima K (2009). The moderating role of reward systems in the relationship between market orientation and new product performance in China. International Journal of Research in Marketing, 26(2): 89-96.

Wei YS and Wang Q (2011). Making sense of a market information system for superior performance: The roles of organizational responsiveness and innovation strategy. Industrial Marketing Management, 40(2): 267-277.

Weick KE (1995). Sensemaking in organization. SAGE Publication, California, USA.

Yu BT and To WM (2013). The effect of internal information generation and dissemination on casino employee work related behaviors. International Journal of Hospitality Management, 33: 475-483. 